\title{
On Station Evaluation of Integrated Agriculture Aquaculture (IAA) on Yield of Potato (Solanum Tuberosum) and Tomato (Lycopersiconesculentum).
}

\author{
Esayas Alemayehu*, Alemayehu Wubie, AbelnehYimer and YaredTigabu \\ Ethiopian Institute of Agricultural Research (EIAR) National Fishery and Aquatic Life Research Centre, Sebeta, \\ Ethiopia.
}

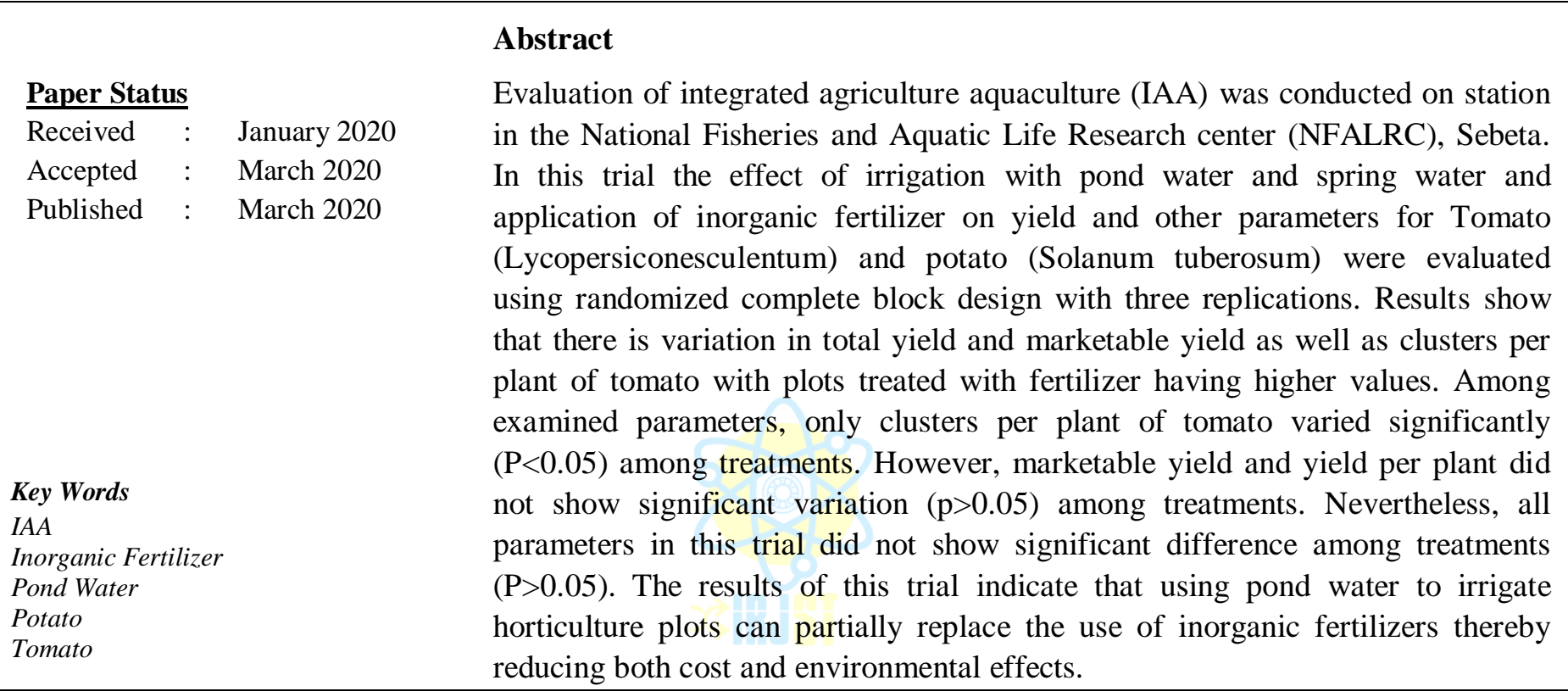

Copyright (C) 2020: Esayas Alemayehu, Alemayehu Wubie, AbelnehYimer and YaredTigabu. This is an open access distribution, and reproduction in any medium, provided Access article distributed under the Creative Commons Attribution License the original work is properly cited License, which permits unrestricted use.

Citation: Esayas Alemayehu, Alemayehu Wubie, AbelnehYimer and YaredTigabu. "On Station Evaluation of Integrated Agriculture Aquaculture (IAA) on Yield of Potato (Solanum Tuberosum) and Tomato (Lycopersiconesculentum):.International Research Journal of Science and Technology, 1 (2) 139-142, 2020.

\section{Introduction}

Declining soil fertility, high input (fertilizers, pesticides, herbicides etc.) costs, dependence on rain fed agriculture and environmental degradation are some of the major challenges facing Ethiopian smallscale farmers. Some of these problems are believed to be addressed by promotion of sustainable resource management system in which physical and biological resources on a farm are integrated in order to give a higher production than would be generated by the individual farming sub system independently.

* Corresponding author: Esayas Alemayehu

Ethiopian Institute of Agricultural Research (EIAR) National

Fishery and Aquatic Life Research Centre, Sebeta, Ethiopia.

Email: esayasalemayehu@gmail.com
One of such systems is the Integrated Aquaculture Agriculture (IAA) system that involves fish farming and other terrestrial based farming systems.

Aquaculture, the cultivation of aquatic organism in a confined water area, presents an opportunity for integration with other agricultural systems as it requires inputs to grow the fish and induce production of plankton as well as produces waste in the form usable by plants. IAA has been advocated to be vital in the development of sustainable aquaculture $[1,2]$.

IAA can be defined as a diversification of agriculture towards nutrient linkages between aquaculture and other terrestrial components within a farm [3]. The key characteristic of the IAA- is the linking of farm components through interconnected flows of nutrients [2]. The objective is to increase the whole farm 
productivity through maximized synergies and minimized antagonisms between components.

In Ethiopia aquaculture can play an important role in providing protein for the small holder farmer. The fish pond can serve as a Centre for integration with other farming systems such as horticulture. Irrigation of crop plots with pond water can reduce the use of fertilizers thereby increasing income for the farmer and reducing environmental impacts of inorganic fertilizer at the same time. The stabilization and increments of household incomes by $36 \%$ in farmers using IAA system has been reported in Malawi [4]. In the Philippines integration of various farm activities with pond culture of fish doubled the income of farmers while increasing the biomass produced by $14 \%$ [1].

The role of IAA in production of vegetables has not been well studied in Ethiopia. Thus, this study was designed to evaluate the production of tomato and potato under IAA system in National Fishery and Aquatic Life Research Center, Sebeta.

\section{Materials and Methods}

On station trial was conducted in the National Fisheries and Aquatic Life Research Center, Sebeta from November 2012 to April 2013. The experiment was conducted by using randomized complete block design (RCBD). Three treatments (pond water, spring water and fertilizer) with 3 replications each were assigned randomly to 9 plots each measuring $3 * 5 \mathrm{~m}$ $\left(15 \mathrm{~m}^{2}\right) .48$ tomato and 48 potato seedlings were planted in each plot with space of $30 \mathrm{~cm}$ and $0.75 \mathrm{~cm}$ between plants and rows, respectively.

Proper management practices including weeding and hoeing took place throughout the growing period while pesticides were applied once. In treatment one, plants were irrigated with spring water while in treatment 2 plants received water from fish pond. Nine ponds stocked with Nile tilapia (Oreochromis niloticus) at 2 fish $\mathrm{m}^{-2}$ served as the source of the pond water for treatment 2. The fish were fed on pelleted feed $(30 \%$ $\mathrm{CP})$ twice daily. In the $3^{\text {rd }}$ treatment fertilizer (DAP and Urea) at $200 \mathrm{~kg}$ per hectare was applied and plots were irrigated by spring water. Concentrations of nutrients $\left(\mathrm{NH}_{3}, \mathrm{NO}_{2}, \mathrm{NO}_{3} \mathrm{SRP}\right.$ and TP) in the pond water and spring water were determined at the beginning of the experiment. Watering of the plants took place twice a day at 08:00and 18:00hrs.

The weight of marketable and unmarketable fruits was determined at each harvest in the tomato experiment. Total yield was then determined as the total weight of fruit from each harvest. The numbers of clusters per plant and number of flowers per cluster of randomly selected plants were totally counted at the third harvest. In the potato experiment the weight of marketable and unmarketable tubers was determined at final harvest. Number of tubers per plant was also determined at this stage. The yield obtained in both experiments was then converted to yield per hectare.

Data was analyzed by the use of R, freely available statistical software. ANOVA was used to see if there is significant difference between treatments. Turkey HD test was applied when significant differences were detected.

\section{Results}

Table 1 summarizes concentrations of nutrients in the pond and spring waters at the beginning of the experiment. Pond water had higher concentrations of $\mathrm{NH} 3, \mathrm{NO} 2$ and TP while spring water had higher concentrations of NO3 and SRP. Table 2 provides some growth parameters of the fish raised during the experiment.

Table 1. Concentrations of nutrients $(\mu \mathrm{g} / \mathrm{l})$ in pond and spring water at the beginning of the experiment

\begin{tabular}{lll}
\hline Nutrients & Pond water & Spring water \\
\hline $\mathrm{NO}_{2}$ & 7.1 & 0.9 \\
$\mathrm{NO}_{3}$ & 99.87 & 133.56 \\
$\mathrm{NH}_{3}$ & 79.13 & 73.37 \\
$\mathrm{SRP}$ & 22.38 & 58.19 \\
$\mathrm{TP}$ & 76.6 & 61.74 \\
\hline
\end{tabular}

Table 2. Some growth parameters of Nile tilapia grown in integrated system with potato and tomato

\begin{tabular}{ll}
\hline Parameter & Values \\
\hline Total Initial weight & $5.1 \mathrm{~kg}$ \\
Total final weight & $17.6 \mathrm{~kg}$ \\
Growth rate & $52.2 \mathrm{~g} / \mathrm{d}$ \\
Yield per hectare & $250 \mathrm{~kg}$ \\
\hline
\end{tabular}

Total yield of tomato per plant ranged from $492.49 \mathrm{~g}$ to $2082.52 \mathrm{~g}$ the highest being recorded in the DAP-Urea fertilized plots and the lowest in the spring water fed plots. Higher total yield per plant was observed in the fertilizer treatment while the spring water treatment showed lowest total yield per plant (Fig 1). However, the observed difference in total yield per plant was not significant $(p>0.05)$ among the treatments. Similarly, total yield was not significantly different $(p>0.05)$ among treatments even though the fertilizer treatment had higher yield than the other two treatments

The highest number of clusters was obtained in the fertilizer treatment and the lowest were found in the spring water treatment (Table 3). Significantly different $(\mathrm{p}<0.05)$ number of clusters was observed among treatments. Tukey HD analysis revealed that fertilizer treatment was significantly different $(p<0.05)$ from both spring water and pond water treatment. However, the difference between pond water treatment 
and spring water treatment was not significant $(\mathrm{p}>0.05)$.

In both total marketable yield and marketable yield per plant of tomato, the fertilizer treatment had higher values and the spring water treatment had the lowest (Table 3). No significant difference $(p>0.05)$ was observed between treatments. Similar results were also found in both the total unmarketable yield and unmarketable yield per plant (Table 3 ). Here also the difference between treatments was observed to be not significant ( $\mathrm{p}>0.05)$.
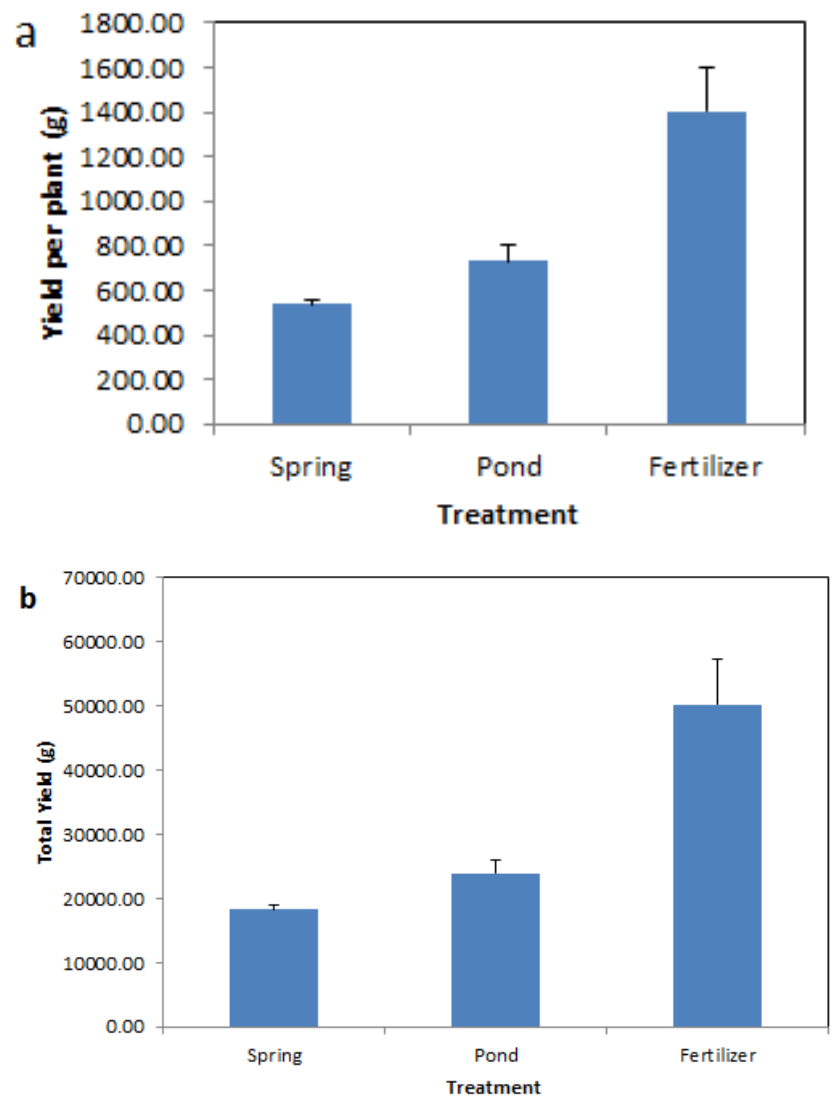

Figure 1.Yield per plant(a) and total yield per plot (b) of tomato fruit in spring water, pond water and fertilizer treatments.

Total yield per hectare of tomato was found to range from 110.3quintals to 496.23 quintals, the highest yield being found in the fertilizer treatment and the lowest in the spring water treatment. Total yield per hectare was not significantly different $(p>0.05)$ between treatments (Table 3 ).

Total yield of potato per plant ranged from $900 \mathrm{~g}$ in spring water treatment to $2006 \mathrm{~g}$ in the fertilizer treatment. (Table 4). However, the observed difference in total yield per plant was not significant $(p>0.05)$ among the treatments. Similarly, total yield was not significantly different ( $p>0.05)$ among treatments even though the fertilizer treatment had higher yield than the other two treatments (Fig 2).
In both total marketable yield and marketable yield per plant of potato, the fertilizer treatment had higher values and the spring water treatment had the lowest (Table 4). No significant difference $(p>0.05)$ was observed between treatments.

Total yield per hectare of potato was found to range from 99.33quintals in spring water treatment to 296.67 quintals, the highest yield being found in the fertilizer treatment and the lowest in the spring water treatment. Total yield per hectare was not significantly different $(\mathrm{p}>0.05)$ between treatments.

\section{Discussion}

In this study yield of both tomato and potato didn't show significant variations among treatments. However, in the tomato yield from the fertilizer treatment was considerably higher than the other two treatments. In contrast the variation in yield of potato among treatments was not significantly different. Similar results were reported in Kenya where fertilizer application had higher yield than pond water irrigation [5]. Increased yields in various crops were also reported when canal water was substituted by pond water [6-8].

The results of this study failed to conclusively affirm the importance of IAA in the yield of vegetables, as significantly different results were not recorded between spring water and pond water treatments. However, absence of significant variation among the fertilizer and the pond water treatments suggest that pond water can partially replace the use of fertilizers especially when the additional yield of the fish is considered.

The fact that yields from the spring water treatment, which served as a control, and the pond water treatment didn't vary significantly can be attributed to the low density of the stocked fish in the ponds which in turn may have resulted in a low concentration of nitrogen. Increased stocking density resulted in increments in $\mathrm{N}$ concentration which had effects on growth of crops (Palada et al., 1999). The finding of comparable concentrations of $\mathrm{P}$ and $\mathrm{N}$ in the spring and pond waters can further strengthen this assertion (Table 1).Wood et al. (2001) found that when $\mathrm{N}$ concentration of $6 \mathrm{mgl}^{-1}$ applied at $2.3 \mathrm{mmd}^{-1}$ resulted in increased yield in French beans.

Higher unmarketable yield was observed in plots treated with fertilizer $(44.5 \%)$ than plots treated with the pond water $(33.4 \%)$. Good quality fruits and lesser unmarketable yield in Bell pepper irrigated with pond water [9]. This finding might be related to the higher number of fruits per plant and the faster rate of growth of the plants in the fertilizer treatment. 
Table 3. Effects of spring water, pond water and fertilizer on number of clusters, marketable and unmarketable yield and total yield per hectare of tomato.

\begin{tabular}{lllllll}
\hline Treatments & $\begin{array}{l}\text { No. of } \\
\text { cluster per } \\
\text { plant }\end{array}$ & $\begin{array}{l}\text { Marketable } \\
\text { yield(g) }\end{array}$ & $\begin{array}{l}\text { Unmarketable } \\
\text { yield(g) }\end{array}$ & $\begin{array}{l}\text { Marketable } \\
\text { yield per } \\
\text { plant }(\mathrm{g})\end{array}$ & $\begin{array}{l}\text { Unmarketable } \\
\text { yield per plant } \\
(\mathrm{g})\end{array}$ & $\begin{array}{l}\text { Total yield } \\
\text { per hectare } \\
(\mathrm{Q} / \mathrm{ha})\end{array}$ \\
\hline Spring & 13 & 16350.50 & 1974.80 & 480.89 & 56.94 & 122.17 \\
Pond & 15 & 17940.77 & 5995.07 & 527.67 & 202.16 & 159.57 \\
Fertilizer & 39 & 34788.67 & 15492.4 & 1024.00 & 378.29 & 335.21 \\
\hline
\end{tabular}

Table 4. Effects of spring water, pond water and fertilizer on marketable and unmarketable yield and total yield per hectare of potato.

\begin{tabular}{lllllllll}
\hline Treatment & $\begin{array}{l}\text { No. } \\
\text { plants }\end{array}$ & $\begin{array}{l}\text { No. of } \\
\text { tubers per } \\
\text { plant }\end{array}$ & $\begin{array}{l}\text { Marketable } \\
\text { yield }(\mathrm{Kg})\end{array}$ & $\begin{array}{l}\text { Unmarketable } \\
\text { yield }(\mathrm{Kg})\end{array}$ & $\begin{array}{l}\text { Yield per } \\
\text { plant }(\mathrm{Kg})\end{array}$ & $\begin{array}{l}\text { Total } \\
\text { yield } \\
(\mathrm{Kg})\end{array}$ & $\begin{array}{l}\text { Yield } \\
\text { hectare }(\mathrm{q})\end{array}$ \\
\hline Spring & 20.33 & 12.17 & 23.17 & 1.97 & 1.11 & 25.13 & 167.56 \\
Pond & 23.33 & 15.78 & 27.67 & 2.50 & 1.26 & 30.17 & 201.11 \\
Fertilizer & 19.00 & 13.33 & 32.67 & 1.67 & 1.72 & 34.33 & 228.89 \\
\hline
\end{tabular}

\section{Conclusion and Recommendation}

This study showed that fish pond water can be used to irrigate horticulture plots to a satisfactory degree. The additional harvest of fish in this system can compensate for the yield difference that is inevitable in the case of reduction in the use of inorganic fertilizers. The properly managed IAA, where ponds can produce the required amount of $\mathrm{N}$ and $\mathrm{P}$ for plants, can be feasible for producing crops and protein for the small holder farmer in Ethiopia.

Further investigations into the optimal amount of water, optimal level of $\mathrm{N}$ and $\mathrm{P}$ in the pond water, optimal stocking density of fish, suitable species of fish and the socio-econmoic impacts of the IAA system should be carried out for a complete and up scalable technology output

\section{References}

[1]. Prein, M., Lightfoot, C. and Pullin, R.S.V. (1995). ICLARM's approach to the integration of aquaculture into sustainable farming systems. In: Devendra, C. and Gardiner,P (eds). Global Agenda for Livestock Research. Proceeding of the Consultation for the SouthEast Asia Region, IRRI, Los Banos, the Philippines. May 10-13, 1995. ILRI, Nairobi, Kenya.

[2]. Prein, M., (2002). Integration of aquaculture into crops-animal systems in Asia. Agricultural system 71, 127-146.

[3]. Little, D.C., Muir, J., (1987). A Guide to Integrated Warm Water Aquaculture. Institute of Aquaculture, University of Stirling, Stirling, UK.
[4]. Lightfoot, C and Noble, R. (1993). A participatory experiment in sustainable agriculture. Journal of Farming Systems Research Extension 4: 1134.

[5]. Wood, C.W., Meso, M. B. and Veverica, K.L. (2001). Use of pond effluent for irrigation in an integrated crop/aquaculture systemIn: A. Gupta, K. McElwee, D. Burke, J. Burright, X. Cummings, and H. Egna (eds), Eighteenth Annual Technical Report. Pond Dynamics/Aquaculture CRSP, Oregon State University, Corvallis, Oregon, pp.69-78.

[6]. Prinsloo, J.F. and Schoonbee, H.J. (1987). Investigations into feasibility of a duck-fishvegetable integrated agriculture-aquaculture system for developing areas in South Africa. Water S.A., 13(2):109-118.

[7]. Al-Jaloud, A.A., Hussain, G., Alsadon, A.A., Siddiqui, A.Q. and Al-Najada, A. (1993). Use of aquaculture effluent as a supplemental source of nitrogen fertilizer to a wheat crop. Arid Soil Res. Rehab.7(3):233-241.

[8]. Hussein, G. and Al-Jaloud, A.A. (1995). Effects of irrigation and nitrogen on water use efficiency of wheat in Saudi Arabia. Agric. Water Manage., 27(2):143-153.

[9]. Palada, M. C., Cole. W. M. and Crossman, S. M. (1999). Influence of Effluents from Intensive Aquaculture and Sludge on Growth and Yield of Bell Peppers. J.Sust. Agri.14(4):85-103. 